Милка Николић

Универзитет у Крагујевцу

811.163.41’367.33:

Филолошко-уметнички факултет ${ }^{2}$

https://doi.org/10.18485/mks_knsjkk.2017.ch14

\section{МОДЕЛИ ПРЕНОШЕЊА ТУЪЕГ ГОВОРА У НАСТАВИ СРПСКОГ КАО СТРАНОГ ЈЕЗИКА}

У овом раду разматрају се модели преношења туђег говора, тј. синтаксичке конструкције којима се исказују туђе речи у српском језику. Циљ је да се испита на који начин треба методички приступити проблематици преношењ $а$ туђег говора у настави српског као страног језика. Према Наставном програму учења и полагања српског језика, предвиђено је да се на Б нивоу обраде основни модели управног и неуправног говора. Предлажемо да се на Ц нивоу студенти упознају са другим моделима преношења туђих речи. На напредном нивоу потребно је да студенти овладају критеријумима према којима се анализирају синтаксичке, морфолошке и ортографске одлике различитих модела преношења туђег говора. Не инсистира се да студенти науче нове термине којима се именују различити модели управног и неуправног говора него да овладају критеријумима анализе и да се оспособе да их примене на аутентичним текстовима. Неопходно је да се код студената унапреде вештине читања и разумевања синтаксичких конструкција преношења туђег говора у различитим функционалним стиловима. Посебна пажња посвећује се вештинама аналитичког и интерпретативног читања уметничког текста, при чему се моделима преношења туђег говора приступа са лингвостилистичког аспекта. Начин на који су синтаксичке конструкције туђег говора остварене у наративној прози посматра се као стваралачки поступак писца. Приликом обраде типова преношења туђег говора у научном функционалном стилу треба успоставити корелацију са обуком студената у академском писању. Овладавање синтаксичким конструкцијама којима се исказују туђе речи у српском језику - омогућава страним судентима који студирају српски језик: (а) да боље разумеју стилистичке нијансе у новинарском и књижевном тексту; (б) да пронађу погоднија решења приликом превођења; (б) да правилно цитирају и парафразирају када пишу научни текст на српском језику.

Кључне речи: говор аутора, туђи говор, преношење туђег говора, директни говор, индиректни говор, синтаксичка конструкција, српски као страни језик.

${ }^{1}$ milkanik75@gmail.com

${ }^{2}$ Овај рад написан је у оквиру пројекта Динамика сиирукйура савременої срйскої језика (2011-2017), број 178014, који финансира Министарство науке и просвете Републике Србије.

\section{1. Увод}

У овом раду се са аспекта методике наставе српског као стра-

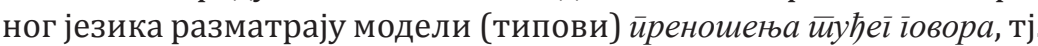
синтаксичке конструкције којима се исказују туђе речи у српском језику. Као што је познато, постоје две граматикализоване форме преношења туђих речи - управни (директни) и неуправни (индиректни) говор, које се разликују по синтаксичким, морфолошким и ортографским карактеристикама. Синтаксичка конструкција којом се преноси туђи говор, по правилу, има дводелну структуру, која обухвата іовор ауйора (ауторска дидаскалија) и їовор „не ауйора” (туђи говор). Модификацијом основних форми управног и неуправног говора настају модели који се одликују најмање једним одступањем у односу на синтакисичку конструкцију од које су настали (на пример, неувеgени управни говор, слобояни управни говор, неконекӣорски неуправни говор, ексиресивни неуправни говор, неуправно-управни говор итд.).

За стране студенте србистике важно је да овладају основним моделима, али и да упознају остале моделе синйаксичких констирукиија туђег говора, што доприноси унапређивању њихових рецептивних, продуктивних и преводилачких вештина. ${ }^{3}$ Циљ овог рада је да се испита на који начин треба методички приступити проблематици йреношења йуђеї іовора у настави српског као страног језика.

У Насиавном йроїраму учења и йолаїања срйской језика наведени су подаци о учењу директног и индиректног говора: (а) за Б1 и Б2 ниво у оквиру синтаксе предвиђена је компетенција која подразумева да полазник: „Уме да пребаци реченице из директног у индиректни говор” (Крајишник, Маринковић 2009: 51, 73); (б) у оквиру правописа за Б1 и Б2 ниво предвиђено је: „Правилно коришћење правописних знака у директном говору (наводни знаци, две тачке, запета, знак узвика, знак питања)" (Крајишник, Маринковић 2009: 53, 75).

\footnotetext{
Проблеми превођења синтаксичких конструкција туђег говора разматрани су у бројним контрастивним истраживањима (Алексић 2016; Ашић, Додиг 2014; Зечевић 2013; Каравесовић, Бубања 2012; Кочовић 2015; Марић 2016; Рајић 1996; Станојевић 2011).
} 
Уџбеници за средњи ниво српског као страног језика придржавају се ових одређења из Настиавної ироїрама приликом обраде граматичких садржаја на средњем нивоу (уп. Alanović, Bjelaković i dr. 2007: 43-44; Vićentijević, Živanić 2007: 95-103). Запажа се да су у уџбеницима обрађене синтаксичке и морфолошке карактеристике директног и индиректног говора, зато је потребно да на средњем нивоу наставник додатну пажњу посвети обради правописних правила. У методичкој литератури указује се да је у бу-

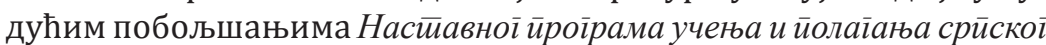
језика неопходно прецизно распоредити правописне садржаје по нивоима, као и да у уџбенике треба унети одговарајуће правописне подсетнике (Брборић 2016: 134). ${ }^{4}$

Пошто се на средњем нивоу обрађују основни моgели управног и неуправног говора, предлажемо да се на напредном нивоу обраде моgели који настају њиховом модификацијом. Студентима треба показати све типове преношења туђег говора тако што ћемо их помоћу синйаксичких, морфолошких и орйоїрафских критеријума повезати у синтаксички подсистем.

На Ц нивоу, употребу синйаксичких консиирукција иреношења

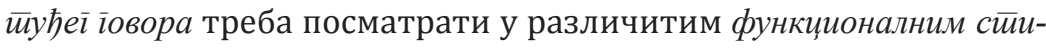
ловима, тј. у неуметничким и уметничким текстовима. На овај начин управни и неуправни говор осветљавају се са функционално-

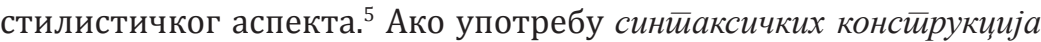

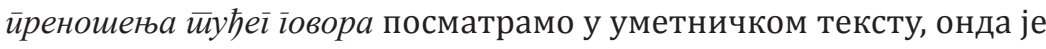

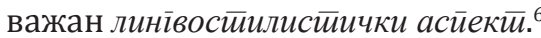

\footnotetext{
${ }^{4}$ Ортографским правилима за обележавање управног говора посвећена је посебна пажња у србистици, при чему су осветљени постојећи проблеми и дата одређена решења (в. Кликовац 2013).

5 У настави српског језика за странце примењује се функционалностилистички приступ (Кончаревић 2004). Познате су вежбе стилског варирања једног жанра, на пример, ауйобиоїрафија као административни и као уметнички текст (в. Ђурић 2013).

${ }^{6}$ Типови туђег говора сматрају се сииилском особином уметничке наративне прозе
} (в. Frangeš 1963).

\section{2. Синтаксички подсистем модела}

преношења туђег говора

У разматрању синтаксичког подсистема конструкција за исказивање туђег говора примењујемо параметре (критеријуме) рейрезенйолоїје, синтаксичке поддисциплине која се бави проблематиком међуодноса їовора ауӣора и іовора „неауйора” (Ковачевић 2015: 253-255). У питању су синтаксички, морфолошки и ортографски критеријуми, на основу којих се описују основни модели директног и индиректног говора, као и модели настали њиховом модификацијом:

(а) Модели уйравноі їовора одређују се према критеријумима које можемо исказати у форми питања: (1) да ли је туђи говор увеgен ауторским говором; (2) да ли је туђи говор ортографски обележен; (3) да ли је туђи говор яословно наведен; (4) да ли је у туђем говору употребљено одговарајуће ірамайичко лиие (које се очекује у управном говору);

(б) Модели неуйравної їовора одређују се према следећим критеријумима (исказаним у форми питања): (1) да ли је туђи говор увеgен ауторским говором; (2) да ли се при навођењу туђег говора употребљава везник изричне реченице; (3) да ли се преноси инйонаuзија туђег говора; (4) да ли је у туђем говору употребљено одговарајуће ірамайичко лице (које се очекује у неуправном говору).

Синтаксички подсистем конструкција за преношење туђег говора у српском језику обухвата следеће типове јединица:

(а) Модели уйравної іовора (УГ) - основни модел УГ, неуведени УГ, неуведени слободни УГ, уведени слободни УГ, фрагментарни УГ, недословни УГ, неизречени УГ, неуправно-управни говор;

(б) Модели неуиравноі їовора (НГ) - основни модел НГ, неконекторски НГ, експресивни НГ, дословни НГ, слободни НГ, полуслободни НГ, полууправни говор.

Сви модели (типови) преношења туђих речи могу се описати помоћу горе наведених критеријума. ${ }^{7}$ То показују истраживања спроведена на текстовима из различитих функционалних стилова: (1) књижевноуметнички стил (Бабић 2014; Вељковић

\footnotetext{
${ }^{7}$ Пошто су модели управног и неуправног говора описани у србистичкој литерату-
} ри, овде их нећемо поново описивати (в. Ковачевић 2012). 
2012; Вељовић 2013; Герун 2016; Живковић, Аксић 2011; Јањушевић Оливери 2015; Русимовић 2010; Николић 2017); (2) административни стил (Павловић 2015); (3) публицистички стил (Ђукић 2017; Јеротијевић 2011; Јеротијевић 2015); (4) научни стил (Марковић 2015).

\section{3. Методички приступ проблематици преношења} туђег говора у настави српског као страног језика

Као што смо претходно указали, у складу са Настиавним йроірамом, страни студенти српског језика на Б нивоу се упознају са синтаксичким, морфолошким и ортографским карактеристикама основних модела директног и индиректног говора. ${ }^{8}$ Настављајући са изграђивањем знања на Ц нивоу, важно је да се студенти упознају са различитим реализацијама навођења туђих речи, и то на примерима из аутентичних текстова, при чему су текстови изабрани из различитих функционалних стилова. ${ }^{9} \mathrm{y}$ уџбеницима за напредни ниво српског као страног језика постоје одломци приповедне прозе и новинарски чланци, који пружају такве могућности: (а) Срйски језик, Део 2, За найреgне (Język serbski, Część 2, Dla zaawansowanych) - уџбеник за студенте у Пољској, аутори су Оливера Душков, Ана Коритовска и Ирена Савицка; (б) Учебник йо сръбски и хърватиски език, Ниво С1/С2 - уџбеник за студенте у Буграској, аутори су Татјана Дункова и Биљана Васић.

Предлажемо да се методички приступ конципира тако да се студент оспособи да анализира реалне примере из корпуса, примењујући критеријуме према којима је успостављен синтаксички

\footnotetext{
${ }^{8}$ Као ослонац за прецизну расподелу правописних садржаја по нивоима у настави српског као страног језика, препоручује се наставни програм српског (матерњег) језика за млађе разреде основне школе (Брборић 2016: 132-134). За наше ученике четвртог разреда основне школе наставним програмом је предвиђено да усвоје правила писања управног и неуправног говора. У уџбеницима за четврти разред, обрада ове правописне јединице спроведена је на одговарајући начин (уп. Драгићевић 2006: 73-76; Николић, Николић 2006: 10-15).

${ }^{9}$ Као што је познато, аутентични текстови у настави страних језика могу допринети циљном и систематском развоју стратегија разумевања и уравнотеженом изграђивању језичких вештина. О дидактичким питањима примене аутентичних текстова у настави страних језика, в. Дурбаба 2006.
}

подсистем модела преношења туђег говора. Дакле, не инсистира се на томе да студент научи све термине којима се именују поједини модели. Показаћемо то користећи текстове из поменутих уџбеника - размотрићемо примере из књижевноуметничког и публицистичког стила.

Наводимо један део одломка из романа Лелејска іора Михаила Лалића, онако како је написани у уџбенику за пољске студенте:

(1) „Šta si stao Lado”, pita me Vasilj i ruga se: „Čitaš li to?” „Oslobađam se prošlosti”, i bacih zakrpu u maglu.

„Nemoj, ne budi lud! Neće ti ništa ostati kad se sasvim oslobodiš, a ne valja da ideš go."

„Ostaće mi šuga i brada, a to nije go."

„Imaš se čime pohvaliti.”

"Imaš li ti nešto bolje?"

On je uobražavao da ima, bi mu krivo kad vidje da nema. Reče da bi bolje bilo da zavežem, ja ga podsjetih da je on prvi počeo i da obično prvi počinje. Lice mu se iskrivi i poče da liči na blijedi mjehur u magli. Teži sam mu, reče, nego Talijani. Teži je on meni, rekoh mu, nego Talijani i četnici zajedno - od njih mogu da pobjegnem bar donekle, a od njega ne. Pa što onda idemo zajedno, upita on, zar ne bismo mogli da se rastanemo... U stvari, njega zabrinjava nešto drugo, ili je umoran, pa vikom, na silu, hoće da se razbudi (Duškov, Korytowska, Sawicka 2010: 14-15).

У наведеном одломку из Лалићевог романа јављају се основни модели преношења туђих речи:

(a) Основни моgел УГ - који препознајемо по (1) ауторској дидаскалији, (2) ортографском обележавању наводницима, (3) дословном навођењу туђих речи и (4) по преношењу граматичког лица које се јавља у говорниковом исказу на пример: „Šta si stao Lado", pita me Vasilj;

(б ) Основни моgел НГ - који препознајемо по (1) ауторској дидаскалији, (2) везнику изричне реченице, (3) по томе што се не преноси интонација туђег говора и (4) по промени граматичког лица у говорниковом исказу, на пример: Reče da bi bolje bilo da zavežem. 
Међутим, јављају се и конструкције које одступају од основних модела директног и индиректног говора, а одступања су следећа:

(a) Конструкција која од основног модела УГ одступа по томе што нема ауторску дидаскалију - ово је одлика неувеgеної УГ, на пример: „Ostaće mi šuga i brada, a to nje go.”;

(б) Конструкција која од основног модела УГ одступа по томе што туђи говор није ортографски обележен наводницима - ово је одлика увеgеної слобоgної УГ, на пример: Pa što onda idemo zajedno, upita on, zar ne bismo mogli da se rastanemo...;

(в) Конструкција која од основног модела НГ одступа по томе што туђи говор није реализован у форми изричне реченице (и нема везника типичног за ову врсту зависних реченица) - ово је одлика

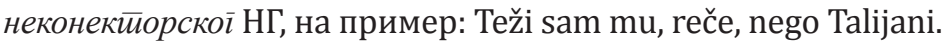

Дакле, потребно је да студент зна карактеристике основно моgела УГ и основной моgела НГ према параметрима које смо навели у претходном делу рада. Помоћу тог ослонца студент проверава да ли у конкретном примеру (у тексту) постоји одступање у односу на карактеристике основних модела. На овај начин користе се критеријуми на основу којих је успостављен синтаксички подсистем конструкција за преношење туђег говора.

Најзахтевнији за анализу јесте слобояни НГ, који се препознаје по томе што приповедач приказује унутрашњи свет јунака, при чему се стапају гласови приповедача и јунака. Ово ћемо илустровати примерима из романа Нечиста крв Боре Станковића (одломак је дат у уџбенику за пољске студенте):

(2) Одједном јој се учини како не може више јер му толико клизе прсти из њене већ ознојене руке, да ће још пре свршеног венчања морати да му испусти руку, и раздвоје се.

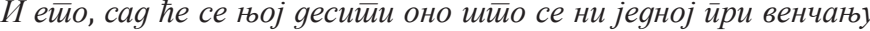
није gоїоgило: яа се све йоквари, јер ииим раздвајањем руку, йаgањем свайовских дарова између њих на йоg, ирекияа се брачна веза (Duškov, Korytowska, Sawicka 2010: 304).

Писци стварају велики број подмодела (подтипова) управног и неуправног говора, на пример: (1) у роману Корени Добрице Ћосића - уиравни іовор испољава се у различитим подмо- делима (в. Русимовић 2010); (2) у роману Крила Станислава Кракова - увеgени gирекйни іовор јавља се у различитим варијацијама (в. Герун 2016); (3) у Друі̄oj књизи Сеоба Милоша Црњанског - слобоgни неуиравни іовор стилизован је на различите начине (в. Вељовић 2013); (4) у збирци Башйа сљезове боје Бранка Ћопића, неизречени слобояни уйравни їовор представља форму унуйрашюе gијалоїа и унуйрашьеї монолоїа, а йок свесиии преноси се слобоgним неуйравним іовором (в. Јањушевић Оливери 2015).

У уметничкој прози синтаксичка конструкција туђег говора често је „изложена” деловању различитих стилистичких поступака. Најједноставнији начин да се стилски неутрална синтаксичка конструкција трансформише у стилем јесте: (1) да се у ауторској дидаскалији употреби неки од глагола који означавају оглашавање животиња, звукове природних појава или звукове одређених предмета (Ковачевић 2015: 262-265); (2) да се употреби стилски маркирана глаголска лексема. Текст под насловом Зов земље Радмила Анђелковића, познатог писца научне фантастике, наведен у уџбенику за пољске студенте, садржи стилогене конструкције туђег говора:

(3) „Хеј, човече..., замкрийао сам најзад (Duškov, Korytowska, Sawicka 2010: 106).

(4) „О’ш да видиш пенџе?”, зарежао сам (Duškov, Korytowska, Sawicka 2010: 106)

(5) „Шта?”, запостављено је кењкао своје питање (Duškov, Korytowska, Sawicka 2010: 108).

(6) „У Старом злату увек траже авантуру?”, исиирйљао je објашњење (Duškov, Korytowska, Sawicka 2010: 108).

У складу с наведеним, предлажемо да се на напредном нивоу користе уметнички текстови у којима се преношење туђег

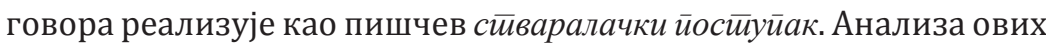
текстова доприноси развоју вештина аналитичког читања с разумевањем, аналитичког читања с интерпретацијом, као и вештина превођења.

Као што је познато, у публицистичком функционалном стилу захтева се верно и прецизно преношење туђих речи. Уџбеници из којих преузимамо примере садрже велики број разноврсних 
новинарских текстова, а реч је о информативним, информативно-аналитичким и књижевно-публицистичким жанровима. ${ }^{10}$ Из тог корпуса издвојили смо одломке који показују различите типове синтаксичких конструкција туђег говора:

(7) Проф. др Марко Бумбаширевић, директор Института за ортопедију, објашњава да сви грађани Србије имају право да се лече у исто опремљеним болницама, јер сви издвајају исту суму новца за здравствено осигурање.

- Док се не направи нови клинички центар, стандард мора да буде исти свуда и сви заслужују да добију исту услугу - сматра др Бумбаширевић (Duškov, Korytowska, Sawicka 2010: 158).

(8) Тим поступком је скренула пажњу на себе, али и навукла гнев појединих политичара, због чега јој се, како каже, живот претворио у хорор филм. Ипак, од даље борбе не одустаје (Duškov, Korytowska, Sawicka 2010: 153).

(9) Одговарајући на питање зашто нема сељака међу посланицима у Скупштини Србије, Д. Ж. Марковић каже да њега то уопште не чуди јер „сељаци гледају своја посла, немају секретаре за паблик рилејшнс, нити могу да плате фолк-певачице да им привуку бираче". Они те паре користе у друге сврхе (Duškov, Korytowska, Sawicka 2010: 233).

(10) Он каже да му никад није био занимљив хотелски смештај.

„То што можеш да идеш преко агенције да те они водају од једне знаменитости до друге није као кад одеш код неког и упознаш га лично, па те он води са својим друштвом на места која су њему битна. Тако упознајеш људе какви су и какви су њихови обичаји" (Дункова, Васич 2015: 103).

(11) Криво му је, признаје, због свега што је урадио. Али је, и каже, свестан да повратка назад нема. Одлучио је да дигне главу и крене напред. Уз дубок уздах, у једном тренутку, ипак признаје да су „дечака убили без везе” (Duškov, Korytowska, Sawicka 2010: 395).

(12) Ова воденица и дан-данас живи животом који се за последња два и по века мало променио. Једино, каже ста-

${ }_{10}$ О примени новинског текста у настави српског као страног језика, в. Дурбаба 2006. ри воденичар, све је мање народа око поточаре, нема више некадашњег вашара од народа око воденичког кола (Дункова, Васич 2015: 91).

Одломци показују да се у новинарским текстовима јављају основни моgел УГ и основни моgел НГ (први одломак садржи такве примере). Применом одговарајућих критеријума у анализи, запазићемо да постоје примери који одступају од основних модела директног и индиректног говора:

(a) Неувеgени УГ - препознаје се по одсуству ауторске дидаскалије, на пример: „То што можеш да идеш преко агенције да те они водају од једне знаменитости до друге није као кад одеш код неког и упознаш га лично [...]";

(б) Увеgени слобояни УГ - препознаје се по одсуству ауторске дидаскалије, на пример: Једино, каже стари воденичар, све је мање народа око поточаре, нема више некадашњег вашара од народа око воденичког кола;

(в) Неконекйорски НГ - препознаје се по томе што туђе речи нису наведене у форми изричне реченице (и нема везника типичног за ову врсту зависних реченица): Криво му је, признаје, због свега што је урадио;

(г) Дословни НГ - одликује се тиме што је под наводницима део изричне реченице којом се наводи туђи говор, на пример: Д. Ж. Марковић каже да њега то уопште не чуди јер „сељаци гледају своја посла, немају секретаре за паблик рилејшнс, нити могу да плате фолк-певачице да им привуку бираче“;

(д) Слобоgни НГ - препознаје се по одсуству ауторске дидаскалије, као и по одсуству форме изричне реченице, на пример: Ипак, од даље борбе не одустаје.

Истраживања показују да су у новинарству, поред основних модела директног и индиректног говора, веома фреквентне слободне структуре туђег говора, као што су увеgени слобояни УГ, неувеgени слобояни УГ и слобояни НГ (Јеротијевић 2011; Јеротијевић 2015). Дакле, новинари одступају од дословног навођења туђих речи.

У том смислу, предлажемо да се на напредном нивоу користе новинарски текстови у којима се јављају реализације слободних форми туђег говора. Посебно треба обратити пажњу на сло- 
боgни НГ, код којег долази до интерференције говора новинара и говора његовог саговорника. Овај тип преношења туђег говора захтева посебне вештине приликом анализе.

Важно је да студент увек има у виду који је функционални стил у питању и које су специфичности преношења туђег говора у датом стилу. То посебно долази до изражаја у научном функционалном стилу, у коме се поштују строге конвенције цитирања и парафразирања. Како показују истраживања, савремени научни текстови садрже „и примере слободног директног говора, што је мање уобичајено" (Марковић 2015: 218). Наиме, слободне форме туђег говора представљају одлику уметничке наративне прозе. „Можемо констатовати да се академски дискурс приближава концепту који се у литератури означава термином хибрияни gискурс" (Марковић 2015: 218).

Проблемима преношења туђег говора у научном тексту треба посветити пажњу у настави српског као страног језика, како би се појачале компетенције студената - и на плану рецепције и на плану продукције научног текста. Приликом обраде типова преношења туђег говора у научном функционалном стилу, треба успоставити корелацију са обуком студената у акаgемском иичсању, што доприноси изграђивању њихових академских компетенција. Ово питање захтева посебан простор за разматрање, па га у складу са предвиђеним обимом рада остављамо за другу прилику.

\section{4. Закључак}

Предлажемо да се методички приступ проблематици ирено-

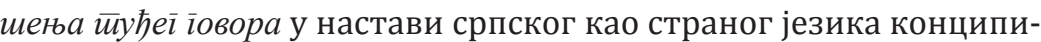
ра на следећи начин:

(a) Након обраде основних модела управног и неуправног говора на Б нивоу (што је предвиђено Насйавним иройрамом учењ а и йолайањ а срииской језика), треба наставити са изграђивањем знања тако што ће се на Ц нивоу студенти упознати и са другим моделима преношења туђег говора.

(б) На напредном нивоу потребно је да студенти овладају параметрима према којима се анализирају синтаксичке, морфолошке и ортографске одлике различитих модела преношења туђег говора. Не инсистира се на томе да студенти науче нове термине којима се именују различити модели управног и неуправног говора, него да овладају критеријумима на основу којих је успостављен синтаксички подсистем конструкција за преношење туђег говора и да се оспособе да их примене на аутентичним текстовима.

(в) Неопходно је да студенти унапреде вештине читања и разумевања аутентичних и функционалностилски разноврсних текстова у којима су реализоване конструкције туђег говора, при чему се обраћа пажња на специфичности преношења туђег говора у сваком функционалном стилу.

(г) Посебна пажња посвећује се вештинама аналитичког и интерпретативног читања уметничког текста, при чему се моделима преношења туђег говора приступа са лингвостилистичког аспекта. Начин на који су синтаксичке конструкције туђег говора остварене у приповедној прози посматра се као стваралачки поступак писца.

(г) Приликом обраде типова преношења туђег говора у научном функционалном стилу, треба успоставити корелацију са обуком студената у академском ииисаґу. На тај начин доприноси се изграђивању академских компетенција код студената.

Овладавање синйаксичким консиирукиијама којима се исказују йуће речи у српском језику - омогућава страним судентима који студирају српски језик: (1) да боље разумеју стилистичке нијансе у новинарском и књижевном тексту; (2) да пронађу погоднија решења приликом превођења; (3) да правилно цитирају и парафразирају када пишу научни текст на српском језику.

\section{ЦИТИРАНА ЛИТЕРАТУРА}

Алексић, М. „Контрастивна анализа реализација слободног неуправног говора у шпанском и српском језику." Филолог̆, бр. 14 (2016) 243-256.

Ашић, Т. Додиг, М. „Слободни индиректни говор у романима Тврђава и Дервиш и смрй Меше Селимовића и његови преводни еквиваленти у француском језику." Наука и ілобализација, 8/1. Ур. Милош Ковачевић. Источно Сарајево: Филозофски факултет, 2014, 377-392. 
Бабић, М. „Однос ауторског и туђег говора у роману Босански иелаӣ Ранка Рисојевића." Наука и ілобализаиија, 8/1 (2014): 143-151.

Брборић, В. „Настава правописа српског језика у настави за странце." О срйском ирравоиичсу. Београд: Друштво за српски језик и књижевност Србије, 2016.

Вељковић, Д. „О типовима говора у роману Сибир Владимира Кецмановића." Раяови Филозофской факулиеейа, бр. 14/1 (2012): 337-348.

Вељовић, В. „Слободни неуправни говор у роману Друїа књиїа Сеоба Милоша Црњанског.” Раgови Филозофской факулиеией, бр. 15/1 (2013): 434-458.

Герун, Б. „Уведени директни говор у роману Крила Станислава Кракова." Филолої, бр. 13 (2016): 213-227.

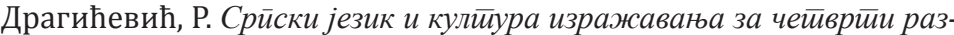
peg основне школе. Београд: Завод за уџбенике, 2006.

Дункова, Т. Васич, Б. Учебник по сръбски и хърватски език, Ниво C1/C2, Част прва. София: Университетско издателство „Св. Климент Охридски", 2015.

Дурбаба, 0. „Новински текстови у настави српског језика као страног.” Научни састианак славистиа у Вукове gане, 32/1 (2004): 271-278.

Дурбаба, 0. „Реафирмација аутентичног текста као новог (старог?) базичног елемента страних језика." Иноващије у настиави, бр. XIX/3 (2006): 16-28.

Ђукић, С. „Компаративна анализа начина и функција преношења туђег говора у штампаним и агенцијским вестима." Кюижевности и језик, бр. LXIV/1-2 (2017): 147-163.

Ћурић, М. „Први час са страним славистима.” Opera Slavica, Slavistické jazykovědný sešit, br. XXIII/4 (2013): 153-163.

Живковић, Н. Аксић, К. „Значај употребе типова говора и речи јунака у моделовању стварности и наративном структурирању Андрићевих приповедака Знакови и Зативорена врайа." Раgови Филозофскої факулйейа, бр. 13/1 (2011): 539-554.

Зечевић, С. „Слободни неуправни говор у роману Вирџиније Вулф To the Lighthouse и његови преводни еквиваленти у српском језику." Наслеће, бр. 26 (2013): 115-126.

Јањушевић Оливери, А. „Типови говора у Башйи сљезове боје Бранка Ћопића." Наука и слобояа, 9/1 (2015): 129-144.

Јеротијевић, Д. „Типови и функције туђег говора у језику српских писаних медија." Раgови Филозофской факулиеейа, бр. 13/1 (2011): 645-660.
Јеротијевић, Д. „Слободне структуре туђег говора у енглеском и српском новинском дискурсу." Наука и слобоgа, 9/1 (2015): 277-293.

Каравесовић, Д. Бубања, Н. „Проблеми књижевног превођења слободног неуправног дискурса са енглеског на српски језик." Срйски језик, бр. XVII/1-2 (2012): 147-160.

Кликовац, Д. „О обележавању управног говора.” Научни састанак слависти а вукове яане, 42/3 (2013): 15-42.

Ковачевић, М. „О граматичко-стилистичком терминосистему туђег говора." Срйски језик, бр. XVII/1-2 (2012): 13-38.

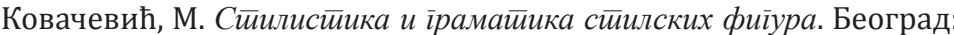
Јасен, 2015

Кончаревић, К. „Функционална стилистика у настави српског је зика као страног (филолошки профил)." Научни састианак славистиа у Byкове яане, 32/1 (2004): 182-191.

Кочовић, М. „Слободни неуправни говор у роману Џејн Остин Гор-

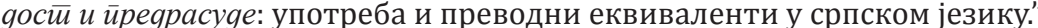
Раяови Филозофской факулиетеиа, бр. 17/1 (2015): 287-298.

Крајишник, В. Маринковић, Н. Тестиови за йолаїање срӣской као

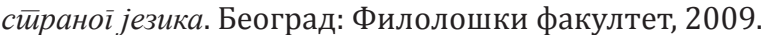

Марић, Б. „Речце у својству показатеља туђег говора у руском и српском језику." Савремено ирроучавање срйской језика и књижевностии и словенских језика као майерњих, инословенских и сирраних II. Ур. Љиљана Бајић. Београд: Филолошки факултет, 2016.

Марковић, Ј. „Модификације директног говора у академском дискурсу." Наука и слобояа, 9/1 (2015): 207-219.

Николић, М. Николић, М. Срйски језик и кулйуйра изражавања за

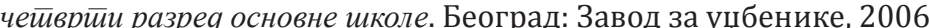

Николић, М. „Стилистика приповедања у стварносној прози Добрила Ненадића." Срисски језик, бр. ХХІ/1-2 (2017): 155-174

Павловић, М. „Типови преношења туђег говора и њима сродне

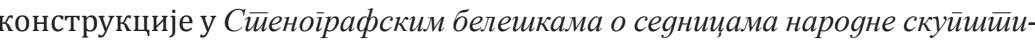
не Краљевине Србије за 1898. Годину." Раяови Филозофскої факулиетей, бр. 17/1 (2015): 447-472.

Рајић, Ј. „Слободни индиректни дискурс у шпанском и могућности његовог превођења на српски." Јужнословенкски филолой, бр. LII (1996): 175-191.

Русимовић, Т. „Експлицирани управни говор у роману Корени Добрице Ћосића." Раяови Филозофскої факулиетйа, бр. 12/1 (2010): 469-478.

Станојевић, М. „Типични говори у роману Чаробни бреї 'О крстионици и о дедином двоструком лику' Томаса Мана и његов превод на српски језик." Раяови Филозофской факулиеетиа, бр. 13/1 (2011): 499-506. 
Alanović, M. Bjelaković, I. Bugarski, N. Dražić, J. Kurešević, M. Vojnović, J. Naučimo srpski 2. Novi Sad: Filozofski fakultet, 2007.

Duškov, O. Korytowska, A. Sawicka, I. Срйски језик, Део 2, За найреgне (Język serbski, Część 2, Dla zaawansowanych). Toruń: Wydawnictwo Naukowe Uniwersytetu Mikołaja Kopernika, 2010.

Frangeš, I. „Slobodni neupravni govor kao stilska osobina.” Umjetnost riječi, br. 4 (1963): 261-275.

Vićentijević, G. Živanić, Lj. Srpski jezik za strance 2. Beograd: Institut za strane jezike, 2007.

\section{МОДЕЛИ ПЕРЕДАЧИ ЧУЖОЙ РЕЧИ В ПРЕПОДАВАНИИ СЕРБСКОГО ЯЗЫКА, КАК ИНОСТРАННОГО}

Предметом настоящей работы являются модели прямой и косвенной передачи чужой речи, т.е. синтаксические конструкции, с помощью которых выражаются чужие слова в сербском языке. Целью работы является описание этих синтаксических конструкций и их изучение в контексте преподавания сербского языка, как иностранного. Модели прямой речи определяются на основании следующих критериев: (1) чужая речь вводится или не вводится авторской речью; (2) чужая речь отмечена или не отмечена орфографическим способом; (3) чужая речь приведена дословно или не дословно; (4) в чужой речи использовано или не использовано соответствующее грамматическое лицо (которое ожидается в прямой речи). Модели косвенной речи определяются на основании следующих критериев: (1) чужая речь вводится или не вводится авторской речью; (2) при передаче чужой речи используется или не используется союз повествовательного предложения; (3) при передаче чужой речи передается или не передается интонация чужой речи; (4) в чужой речи использовано или не использовано соответствующее грамматическое лицо (которое ожидается в косвенной речи). Знание синтаксических конструкций, которыми передаются чужие слова в сербском языке - позволяет иностранным студентам, изучающим сербский язык: (а) правильно цитировать и парафразировать при написании научного текста на сербском языке; (б) лучше понимать стилистические нюансы в газетном и литературном тексте; (в) найти самые удачные решения при переводе.
Зорана Опачић

Учитељски факултет у Београду

Универзитет у Београду

https://doi.org/10.18485/mks_knsjkk.2017.ch15

\section{ИДЕНТИФИКАЦИЈА И ЊЕНА ОГРАНИЧЕЊА У ТУМАЧЕЊУ КЊИЖЕВНОГ ТЕКСТА (ОД ПРЕТПОСТАВЉЕНОГ ДО КРИТИЧКОГ ЧИТАОЦА)}

У раду ћемо се бавити разликом између позиције подразумеваног и критичког читаоца, полазећи од тврдње Марије Николајеве (2010) да независни критички однос према тексту спада у најважније читалачке компетенције, а он је често супротан конструкцији подразумеваног читаоца. Пошто се овај приступ често примењује у настави књижевности, у раду ћемо посветити пажњу овом поступку и указати на његове добре стране и његове слабости. Потпуна идентификација са фокализатором је читалачка стратегија која се нашироко практикује у школама и многи оспоравају адекватност таквог поступка, пошто ствара илузију да читалац влада текстом, а он је заправо високо изложен идеологији текста, сматра и Стивенс (1992).

Указаћемо на примерима различите видове остваривања идентификације: са становиштем приповедача, са позицијом главног јунака-фокализатора, са позицијом споредног јунака. Затим ћемо указати на типове текстова у којима је идентификација отежана или онемогућена: текстови са йеgаїошким кониексииом, у којима се читалац охрабрује да усвоји моралистички поглед на свет; жанровске конвениије; дела заснована на наийрирояном јунаку који се појављује ниоткуда, поседује натприродне моћи, утиче на животе других и нестаје; ирийовеgање у йрвом лииу (које у омладинском роману омогућава илузију аутентичног тинејџерског гласа, што охрабрује читаоца да усвоји његову позицију); рейросиекииивно йрийовеgање (одрасли приповедач sе сећа детињства, па се минуло време изнова конструише уз накнадне коментаре и симболизацију догађаја). Како би читалац био у стању да што потпуније разуме смисао књижевног дела и вишеструкост његових значења, он треба да чини супротно од идентификације - да покуша да га посматра из различитих позиција. Као медијатори између књижевног текста и младе читалачке публике, желимо да ученици буду у стању да заузимају различите перспективе и развију разумевање и емпатију - односно да постану самосвесни, критички читаоци.

Кључне речи: подразумевани читалац, критички читалац, приповедни дискурс, објективизација читаоца, идентификација са становиштем приповедача, јунак-фокализатор, отежана идентификација, настава књижевности.

${ }^{1}$ zorana.opacic@gmail.com 